\title{
Incidence of chewing lice (Phthiraptera: Insecta) on common pea fowls (Aves: Galliformes) from district Hyderabad, Sindh, Pakistan
}

\author{
Farheen Shaikh ${ }^{1 *}$, Saima Naz ${ }^{1}$ and Nadir Ali Birmani ${ }^{1}$ \\ 1. Department of Zoology, University of Sindh, Jamshoro-76080, Sindh, Pakistan \\ *Corresponding author's email: fshaikh700@yahoo.com

\section{Citation} \\ FarheenShaikh, Saima Naz and Nadir Ali Birmani. Incidence of chewing lice (Phthiraptera: Insecta) on common pea \\ fowls (Aves: Galliformes) from district Hyderabad, Sindh, Pakistan. Pure and Applied Biology. Vol. 11, Issue 2, \\ pp518-526. http://dx.doi.org/10.19045/bspab.2022.110051
}

\begin{tabular}{llll}
\hline \hline Received: 26/05/2021 & Revised: 30/07/2021 & Accepted: 05/08/2021 & Online First: 26/08/2021
\end{tabular}

\section{Abstract}

The chewing lice (Insecta: Phthiraptera) are dorsoventrally flattened and wingless insects. The lice have strong mandibles for biting tissue debris and body feathers of their hosts. They have high capability to develop host specificity and cause acute to chronic effects on fitness of their hosts. They are responsible for numerous illnesses and also play a role as vector of some bacteria and helminthic worms. Presently, one type of large sized galliform bird, Common pea fowl Pavocristatus was selected for collection, identification, population density and rate of infestation of the parasitic insects, chewing lice from urban and rural areas of district Hyderabad Sindh, Pakistan. 20 Common pea fowl Pavocristatus were collected for chewing lice. The study was conducted from December 2016 to October 2017. Common pea fowls were kept on white paper sheet for about 30 minutes and sprayed through coopex powder (Permathrin) in their wings. The infested birds were tagged with identity rings to check their lice population after interval of 2 to 3 weeks. The collected lice were preserved in $75 \%$ ethanol. The permanent microscopic slides were prepared with canada balsam through standard method of preservation. Presently total 150 chewing lice specimens were recovered which belongs to 04 genera of 02 families. These species and their prevalence are 33.33\% for Colpocephalum tausi (Nitzsch, 1818) 24.01\% for Menacanthus stramineus (Nitzsh, 1818), and $14.01 \%$ for Menacanthus pallidulus(Neumann, 1912) belongs to family Menoponidae $18.01 \%$ Goniodes dissimilis, Denny, 1842 and $10.67 \%$ for Lipeurus tropicalis, Peters, 1931 belongs to family Philopteridae. All these five species were reported first time as new host and new locality record from the study area. The result of present study revealed that one of a cause of reduced production of eggs, meat and feathers in poultry birds is the presence of chewing lice on their body which causes weakness, sickness, lethargicness and fatalness in game birds. All lice species were studied and described comprehensively.

Keywords: Common pea fowl; Ectoparasites; Hyderabad; Menoponidae; Philopteridae; Population density

\section{Introduction}

Phasianidae is the largest family. It belongs to the order galliforme which includes more than 150 species. They are commonly known as game birds [1]. They are moderate to large sized, terrestrial, sedentary, resident, colorful, attractive versatile and beautiful birds. These birds are common in our region and are mostly kept in captivity by humans for their eggs; 
feathers and meat production [2]. They have great diversity in their behaviors, habitat, life style and feeding habits. Fowls are easy to rear and handle by householders. They are with three pairs of clasping types of legs terminating to one or two tarsal claws [2]. Game birds are one of the most populous life form and also excellent indicators of health of many ecosystems. The common pea fowl Pavocristatus is commonly called forest bird. The males are recognized for their sharp and deafening calls and profligate feathers, have eye dotted tail. Male fowls have metatarsal spurs on their legs that are used during intraspecific regional fight with other fellows of their kind. The females are known as peahens $[3,4]$. The birds are omnivorous, and regularly eat certain parts of plant, like flowers petals, seed skulls, insects and other amphibians, reptiles and arthropods [5]. Phasianidae family is largest family of galliform birds include, other than fowls, it also includes Lerwalerwa (Snow partriges), Tetraogalluhi malayensis (Ram chukar), Alectoris chukar (Rock partridge or Chukar), Ammoperdixgriseo gularis (See-see partridges), Francolinus francolinus (Black partridges or Black francolin), Francolinus pondicerianus (Grey francolin or Indian grey partridges), Coturnix coturnix (Common quail or Grey quail), Coturnix coromandelica (Rain quail or Black-breasted quail), Tragopanmelano cephalus (Western tragopan) [6, 7]. There are about ten (10) species of chewing lice which parasitize different breeds of Common pea fowl Pavocristatus and cause infestation throughout the world [8]. These species belong to family Menoponidae (suborder Amblycera) and family Philopteridae (suborder Ischnocera). They cause from lesser amount to increase rate of infestation among galliformbirds worldwide. The world reported species of Pavocristatus are Amyrsidea minuta (Emerson, 1961),
Amyrsidea phaeostoma (Nitzsch, 1866), Colpocephalum tausi (Ansari, 1951), Colpocephalum thoracicum (Kellogg and Paine, 1914), Goniocotes mayuri (Lakshminarayana and Emerson, 1971), Goniodes meinertzhageni (Clay, 1940), Goniodes pavonis (Linnaeus, 1758), Lipeurus pavo (Clay, 1938), Menacanthus kaddoui (Eichler and Mey, 1978) and Menacanthus stramineus (Nitzsch, 1818) established all over the world.

From Pakistan, only few galliformbirds (fowls) of northern areas and Punjab have been studied in order to recognize their chewing lice [1, 9-12]. Previously there was no significant work is done from Sindh region or other parts of Pakistan on fowls particularly, except one of few chewing lice species were reported $[13,14]$. Due to the lake of information of these ectoparasites in Hyderabad region, the present study was designed and contributed the updated records of chewing lice of fowls in the world.

\section{Materials and Methods}

District Hyderabad is situated in province of Sindh Pakistan. It is placed 140 kilo meter east of Karachi. It is the second largest city in province. District Hyderabad is placed on the east bank of the River Indus and (93 miles) away from Karachi. It has warm desert temperature with hot conditions year around [13]. The Hyderabad city is famous for its changed weather which moderates the temperature. Its temperature and humidity is remains high and it has warm winter season (Fig. 1). Present research work was carried out between December 2016 to October 2017. A total of 20 specimens of Common pea fowl Pavocristatus were examined for chewing lice population from different localities of district Hyderabad, including Hyderabad city, Tando Fazal, Tando Agha, Tando Jam and Shah Bukhari (Table 1) Sindh, Pakistan. In present study urban and rural areas were selected for collection, identification and population density of 
chewing lice fauna. Fowls were captured from their natural environment which was available in captivity. Each bird was kept in white paper sheet sprinkled through permathrin powder for about of 30 minutes and carefully searched chewing lice species on collar, belly, abdominal and tail feathers of hosts. All lice specimens are collected preserved in $75 \%$ ethylic alcohol and finally mounted in Canada balsam with the help of cover slips [15]. Observation occurred month wise except May and November in order to allow the eggs to hatch and grow the population of lice. The experiments were conducted in both summer and winter seasons. The winter collection was carried out during December 2016 to April 2017 and the summer collection was carried out during June 2017 to October2017 in order to check the effects of climatic conditions.
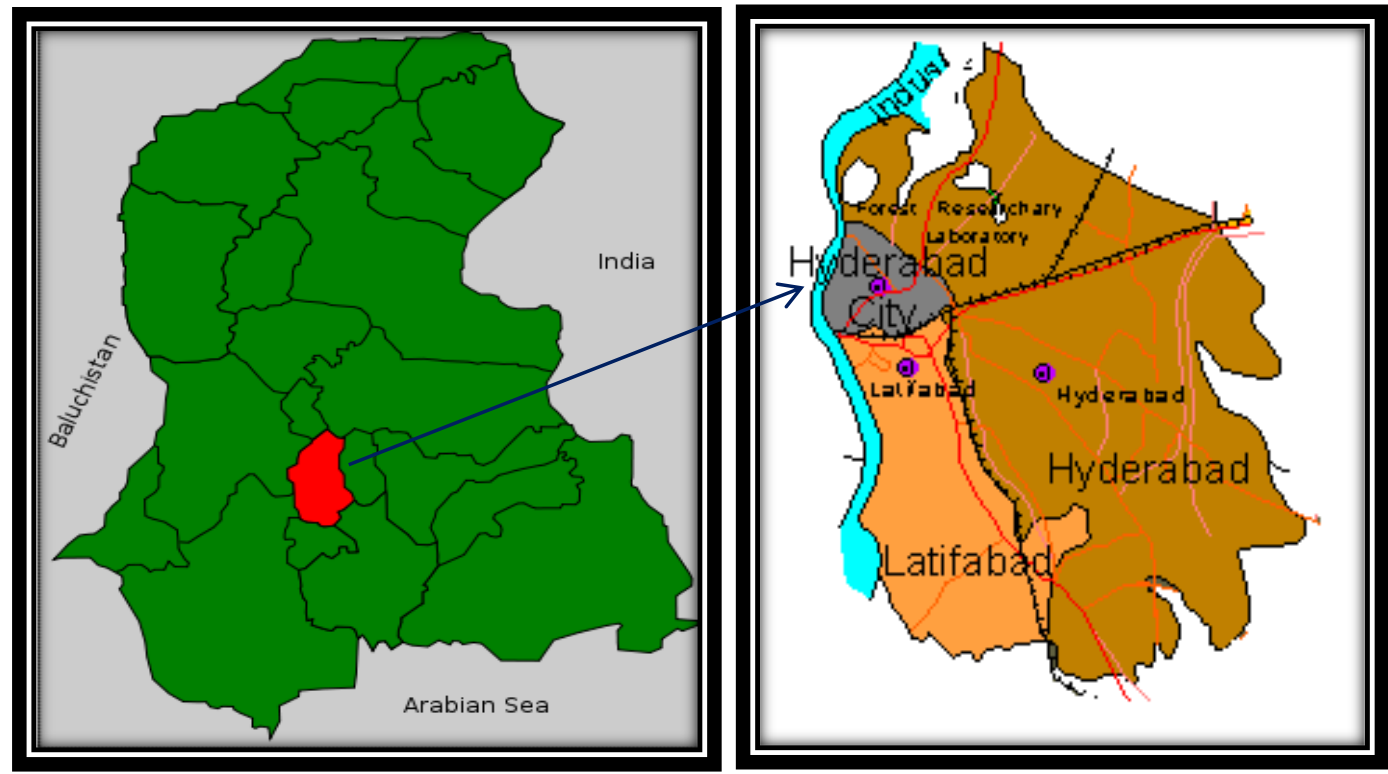

Figure. 1 Study area Hyderabad

Table 1. The chewing lice of pea fowl Pavocristatus collected from various localities of Hyderabad during year December 2016-October 2017

\begin{tabular}{|c|c|c|c|c|c|c|c|c|}
\hline Locality & $\begin{array}{c}\text { Total no. } \\
\text { of fowls } \\
\text { examined }\end{array}$ & $\begin{array}{c}\boldsymbol{C} . \\
\text { tausi }\end{array}$ & $\begin{array}{c}\boldsymbol{M} . \\
\text { stramineus }\end{array}$ & $\begin{array}{c}\boldsymbol{M} . \\
\text { gallinae }\end{array}$ & $\begin{array}{c}\boldsymbol{L} . \\
\text { tropicalis }\end{array}$ & $\begin{array}{c}\boldsymbol{G} . \\
\text { dissimilis }\end{array}$ & $\begin{array}{c}\text { Total lice } \\
\text { in each } \\
\text { locality }\end{array}$ & $\begin{array}{c}\text { Population } \\
\text { densiy }\end{array}$ \\
\hline Hyderabad city & 04 & 09 & 05 & 03 & 02 & 04 & 23 & 5.75 \\
\hline Tandofazal & 04 & 08 & 08 & 05 & 04 & 05 & 30 & 7.5 \\
\hline Tando Agha & 04 & 11 & 08 & 04 & 03 & 06 & 33 & 8.25 \\
\hline Tando Jam & 04 & 10 & 06 & 03 & 04 & 04 & 27 & 6.75 \\
\hline Shah Bukhari & 04 & 12 & 09 & 06 & 03 & 08 & 38 & 9.5 \\
\hline $\begin{array}{c}\text { Total birds and } \\
\text { lice species }\end{array}$ & 20 & 50 & 36 & 21 & 16 & 27 & 150 & 7.5 \\
\hline $\begin{array}{c}\text { Overall } \\
\text { incidence of } \\
\text { chewing lice } \\
\text { species }\end{array}$ & 33.33 & 24.01 & 14.01 & 10.67 & 18.01 & 99.98 & \\
\hline $\begin{array}{c}\text { Population } \\
\text { abundance of } \\
\text { all chewing } \\
\text { lice species }\end{array}$ & & 2.5 & 1.8 & 1.05 & 0.5 & 1.35 & 7.5 & \\
\hline
\end{tabular}




\section{Results and Discussion}

Total 20 fowls were examined, 11 went positive with $55.01 \%$ prevalent to their lice species, which is a high abundance of their infestation. Chewing lice species were collected during present study belongs to 04 genera of 02 families Menoponidae and Philopteridae. The variety of host distribution for the genus Colpocephalum, Menacanthus, Lipeurusand the genus Goniodess have proven to be the most interesting result. The study was conducted in different localities of district, Hyderabad, includes Hyderabad city, Tando Fazal, Tando Agha and Shah Bukhari from Sindh, Pakistan. First the calculation was made (Table 1 \& Fig. 2) on the Prevalence of 05 types of Chewing lice species on Common pea fowl Pavocristatus and then their main taxonomic characters were described along with their measuring body parts (Table 2 ) from the study area.

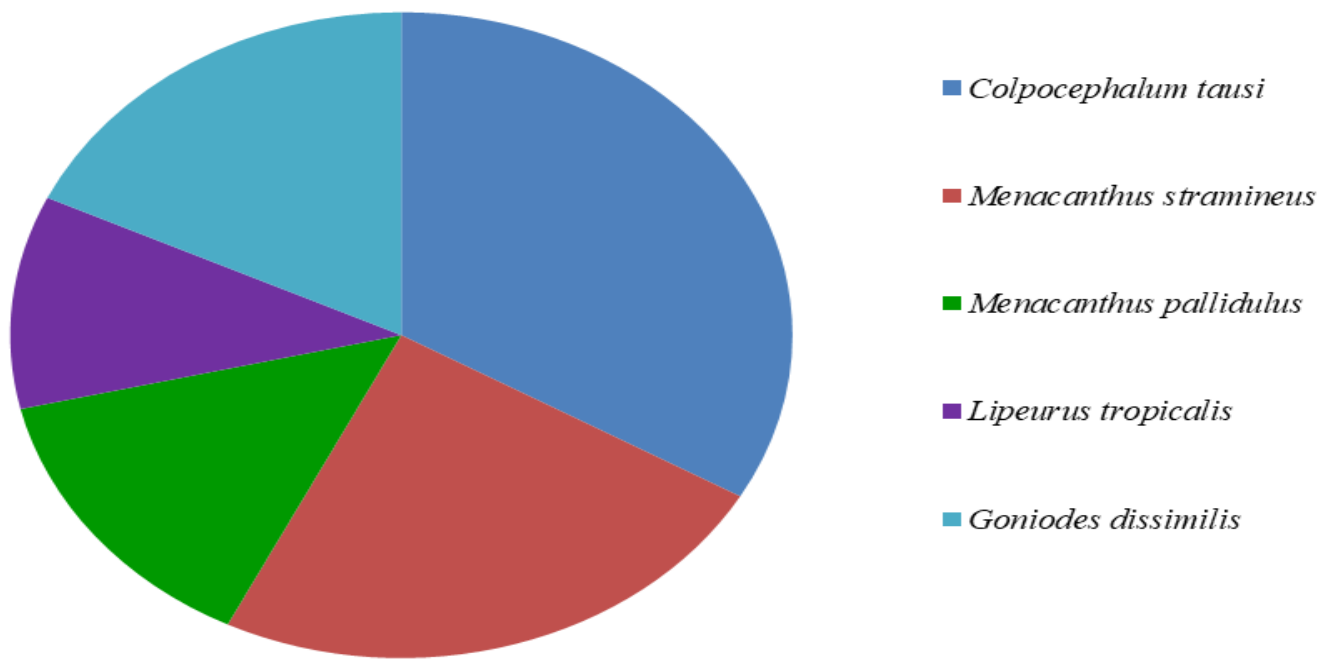

Figure 2. Percentage representation of the prevalence of host for chewing lice infestation during present study

Table 2. Measurements of body parts of all type species in $\mathbf{m m}(\mathbf{n}=\mathbf{3})$

\begin{tabular}{|c|c|c|c|c|c|}
\hline Body Parts & C. tausi & M. stramineus & M. pallidulus & G. dissimilis & L.tropicalis \\
\hline Total length (TL) & 1.44 & 2.894 & 1.526 & 2.175 & 3.304 \\
\hline Head length (HL) & 0.28 & 0.366 & 0.311 & 0.695 & 0.724 \\
\hline Preocular width (POW) & 0.35 & 0.534 & 0.379 & 0.825 & 0.503 \\
\hline Temporal width (TW) & 0.47 & 0.671 & 0.506 & 0.780 & 0.504 \\
\hline Prothorax length (PL) & 0.144 & 0.276 & 0.199 & 0.197 & 0.244 \\
\hline Prothorax width (PW) & 0.304 & 0.541 & 0.376 & 0.471 & 0.38 \\
\hline Metathorax length (ML) & 0.187 & 0.191 & 0.146 & 0.648 & 0.398 \\
\hline Metathorax width (MW) & 0.373 & 0.589 & 0.407 & 0.686 & 0.592 \\
\hline Abdominal length (AL) & 0.76 & 1.914 & 0.905 & 0.961 & 2.02 \\
\hline Genital length (GL) & 1.31 & 0.699 & 0.330 & 0.873 & 0.55 \\
\hline Genital width (GW) & 0.21 & 0.254 & 0.088 & 0.06 & 0.091 \\
\hline Head Index (HI) & 1.678 & 1.833 & 1.627 & 1.122 & 0.696 \\
\hline
\end{tabular}

\section{Colpocephalumtausi (Nitzsh, 1818)}

Type host: PavocristatusLinnaeus. (Table 3) Small size dark yellow menoponid, frequently not common chewing lice on other galliform birds of family Phasianidae, highly prevalent to Common pea fowl Pavocristatus. It is fast moving amblycera. During present study 50 specimens recovered 
and prevalence of $33.33 \%$ on host body. (Table 4). It was reported first time from Hyderabad as new locality record on Common pea fowl Pavocristatus. It is with broad circumfasciate head margin surrounded by a pair of plucky spiniform setae; occipital and ocular nodi very clear; antennae long through three pairs of setae; hypopharynx well developed; tergites complete; male genitalia elongated, basal plate constricted, penis slightly broad, parameres small size and simple (Fig. 3).

\section{Material examined}

$18 \lesssim$ and 32 on Pavocristatus Linnaeus found from abdomen, head, tail feathers, legs, breast; Sindh, Pakistan, December 2016 to October 2017.

Menacanthus stramineus (Nitzsh, 1818)

Type Host: Meleagris gallopavo Linnaeus (Table 3).

Large size dark yellow pigmented body, most common in all types of Phasianid poultry birds. During present study 36 specimens recovered and prevalence of $24.01 \%$ on host body (Table 4). It is reported first time from Hyderabad, as new host and new locality record on Common Pea fowl Pavocristatus; previously it was reported from Karachi by [13] on domestic fowls. The anterior rmargin of head circumfasciate, preocular slit deep and sufficient, gular plate evident, antennae long; tergites complete and ovoide to oblong; male genitalia very typical, enlarge and reaching up to the segment VI, genital sclerites well established, parameres elongated with broad basal apodeme (Fig. 4).

\section{Material examined}

$16 \widehat{\supset}$ and 20 on Pavocristatus Linnaeus found from belly, head, tail feathers, legs, breast; Sindh, Pakistan, December 2016 to October 2017.

Menacanthus pallidulus (Neumann, 1912)

Type Host: Gallus gallus Linnaeus (Table 3) Small size dark yellow pigmented menoponid found almost on all species of family phasianidae. It is more active lice and remains move around the body feathers. During present study 21 specimens were recovered and prevalence of $14.01 \%$ on host body (Table 4). It is reported Second time from Hyderabad, Sindh, Pakistan as new locality record on Common pea fowl Pavocristatus. It was first time reported from Karachi by [13] on domestic fowls. The anterior head margin circumfasciate, smooth and rounded, antennae long, hypopharynx well developed, gular plate developed, ocular and occipital nodi not evident; tergites broad and complete includes segments I to VIII; male genitalia short, limited behind the segment VI, basal apodeme broad, rounded and flat, penis small size through rounded tip (Fig. 5)

\section{Material Examined}

$09 \widehat{\jmath}$ and 12 on Pavocristatus Linnaeus found from abdomen, head, tail feathers, legs, breast; Sindh, Pakistan, December 2016 to October 2017.

\section{Goniodes dissimilis, Denny, 1842}

Type Host: Gallus gallus Linnaeus (Table 3). Dark yellow small size philopterid generally common lice species of galliform birds of family Phasianidae. It is less active Ischnocera and most of the time remains attached to feathers. During present study 27 specimens were recovered and prevalence of $18.01 \%$ on host body (Table 4). It is first time reported from Hyderabad, Sindh Pakistanas new host and locality record on Common Pea fowl Pavocristatus. The anterior head margin circumfasciate, broad and rounded, antennae heteromorphic; abdomen large size, broad, oblong with curved margin, tergoplurites darkly pigmented; male genitalia very enlarge and reaching up to the abdominal segment IV, constricted, elongated and flat basal apodeme, penis small size attached through mesosomal plate (Fig. 6).

\section{Material examined}

$10 \hat{\jmath}$ and $17 \not$ on Pavocristatus Linnaeus found from abdomen, head, tail feathers, 
legs, breast; Sindh, Pakistan, December 2016 to October 2017.

\section{Lipeurus tropicalis, Peters, 1931}

Type Host: Gallus gallus Linnaeus (Table 3). Body elongated, dark pigmented philopterid, commonly known as chicken head louse, generally found underside of head feathers. During present study 16 specimens were recovered and prevalence of $10.67 \%$ on host body (Table 4). It is reported first time from Hyderabad, Sindh, Pakistan as new host and new locality record from Common Pea fowl Pavocristatus. Theanterior head margin narrow, circumfasciate, rounded and smooth, antennae heteromorphic, gular plate evident; tergites complete modified as hourglass plate shaped; male genitalia very enlarge reaching up to the segment IV, richly sclerotized, basal apodeme elongated tapering toward anterior end, parameres simple and straight Fig. 7).

Material examined $06 \hat{\delta}$ and $10+$ on Pavocristatus Linnaeus found from abdomen, head, tail feathers, tail, breast; Sindh, Pakistan, December 2016 to October 2017.

The present study is aimed to encounter the chewing lice species of economically important bird, fowls (Common pea fowl). Poultry birds are important game birds. The present study provides a basic knowledge to identify these parasites and awareness to the poultry breeders and hence to improve the production of poultry industry. During present research work of five species of chewing lice Colpocephalum tausi (Nitzsh, 1818) Menacanthus stramineus (Nitzsh, 1818), Menacanthus pallidulus (Neumann, 1912) belongs to family Menoponidae, Goniodes dissimilis, Denny, 1842, Lipeurus tropicalis, Peters, 1931 belonging to family family Philopteridae were identified and described in details on Common Pea fowl Pavocristatus from five various localities of Hyderabad, Sindh, Pakistan. The most prevalent species was recorded Colpocephalum tausi with $33.33 \%$ and 2.5 intensity whereas the least prevalent species was Lipeurus tropicalis with $10.67 \%$ and 0.8 intensity (Table 4, Fig. 8). The temperature and humidity are very important elements in increasing the population of lice on the host body. During the summer season the population of lice increases as compared to the winter season $[16,17]$. It was observed by experiments that the ectoparasites of humid and warm regions grow and multiply more rapidly than the parasites of arid regions [18].

Table 3. Chewing lice collected during present study from Common pea fowl Pavocristatus of Hyderabad with their type host

\begin{tabular}{|c|c|c|c|c|}
\hline Suborder & Family & Genera & Species & Type Host \\
\hline \multirow{3}{*}{ 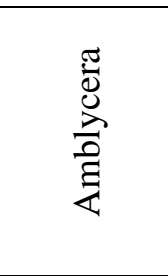 } & \multirow{3}{*}{ Menoponidae } & \multirow{2}{*}{ Menacanthus } & $\begin{array}{l}\text { M. Stramineus } \\
\text { (Nitzsch, 1818) }\end{array}$ & Meleagrisgallopavo \\
\hline & & & $\begin{array}{c}\text { M. pallidulus } \\
\text { (Neumann 1912) }\end{array}$ & Gallus gallus \\
\hline & & Colpocephalum & $\begin{array}{c}\text { C. tausi } \\
\text { (Ansar, 1951) }\end{array}$ & Pavocristatus \\
\hline \multirow{2}{*}{$\begin{array}{l}\dot{\bar{d}} \\
\stackrel{0}{0} \\
\stackrel{\Xi}{0} \\
\dot{0}\end{array}$} & \multirow{2}{*}{ Philopteridae } & Goniodes & $\begin{array}{l}\text { G. dissimilis } \\
\text { Denny } 1842\end{array}$ & Gallus gallus \\
\hline & & Lipeurus & $\begin{array}{c}\text { L.tropicalis } \\
\text { (Peters, 1931) }\end{array}$ & Gallus gallus \\
\hline
\end{tabular}


Table 4. Chewing lice collected during the present study from Common pea fowl of Hyderabad region with their rate of infestation and prevalence (\%)

\begin{tabular}{|c|c|c|c|c|c|c|}
\hline $\begin{array}{l}\text { S. } \\
\text { No. }\end{array}$ & Name of lice species & $\begin{array}{l}\text { No. of birds } \\
\text { examined }\end{array}$ & $\begin{array}{l}\text { No. of birds } \\
\text { Infested }\end{array}$ & $\begin{array}{l}\text { No. of lice } \\
\text { collected }\end{array}$ & $\begin{array}{l}\text { Intensity of } \\
\text { Parasitism }\end{array}$ & $\begin{array}{c}\text { Prevalence } \\
\%\end{array}$ \\
\hline 1 & Colpocephalumtausi & 04 & 03 & 50 & 2.5 & 33.33 \\
\hline 2 & Menacanthusstramineus & 04 & 02 & 36 & 1.8 & 24.01 \\
\hline 3 & Menacanthuspallidulus & 04 & 02 & 21 & 1.05 & 14.01 \\
\hline 4 & Goniodesdissimilis & 04 & 02 & 27 & 0.8 & 18.01 \\
\hline 5 & Lipeurustropicalis & 04 & 02 & 16 & 1.35 & 10.67 \\
\hline & Total & 20 & 11 & 150 & 7.5 & 99.99 \\
\hline
\end{tabular}

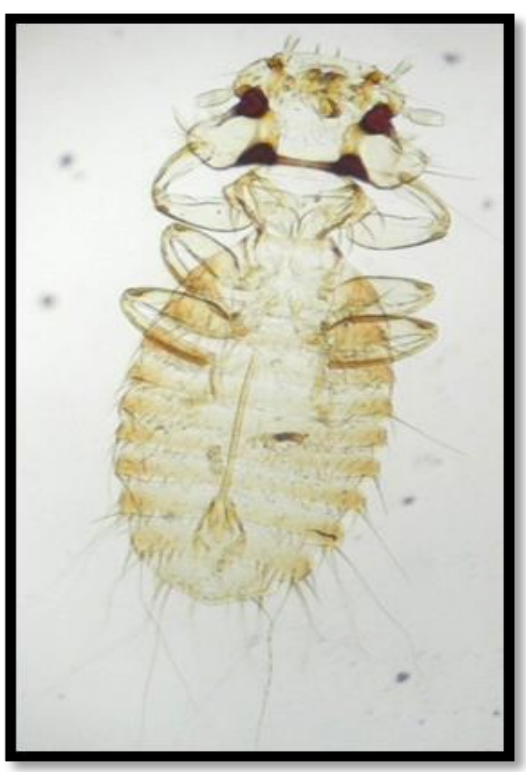

Figure 3. Colpocephalum tausi

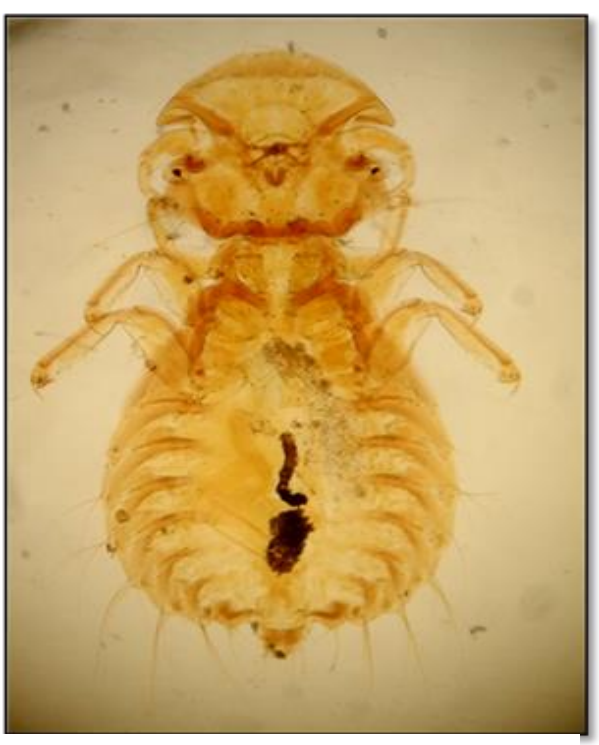

Figure 6. Goniodes dissimilis

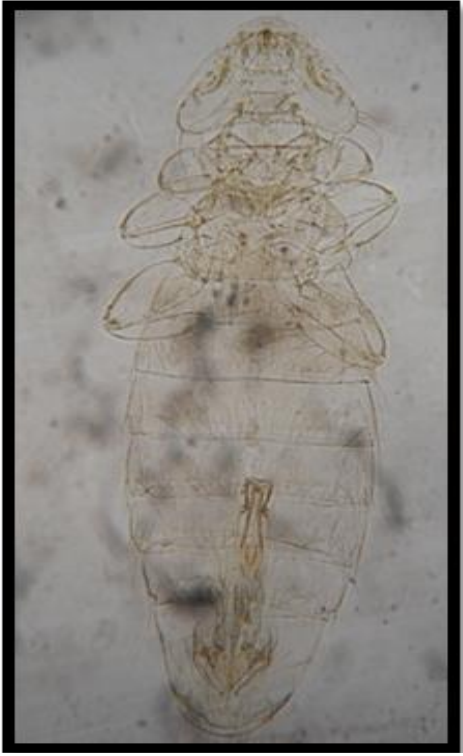

Figure 4. Menacanthus stramineus

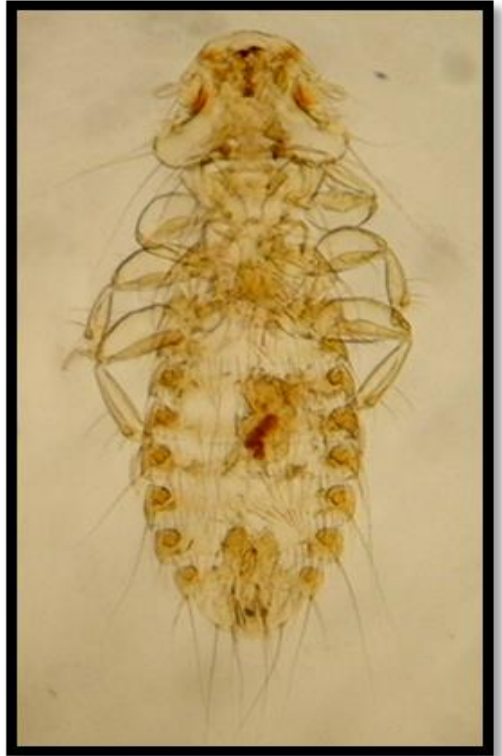

Figure 5. Menacanthus pallidulus

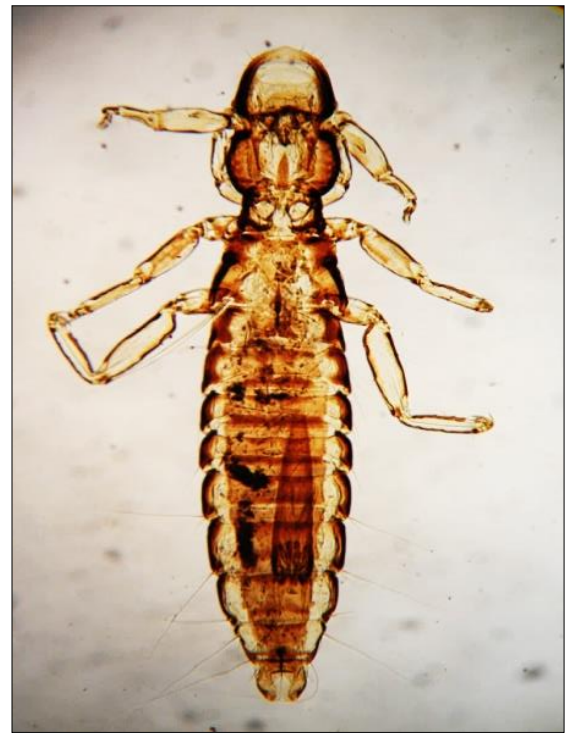

Figure 7. Lipeurus tropicalis 


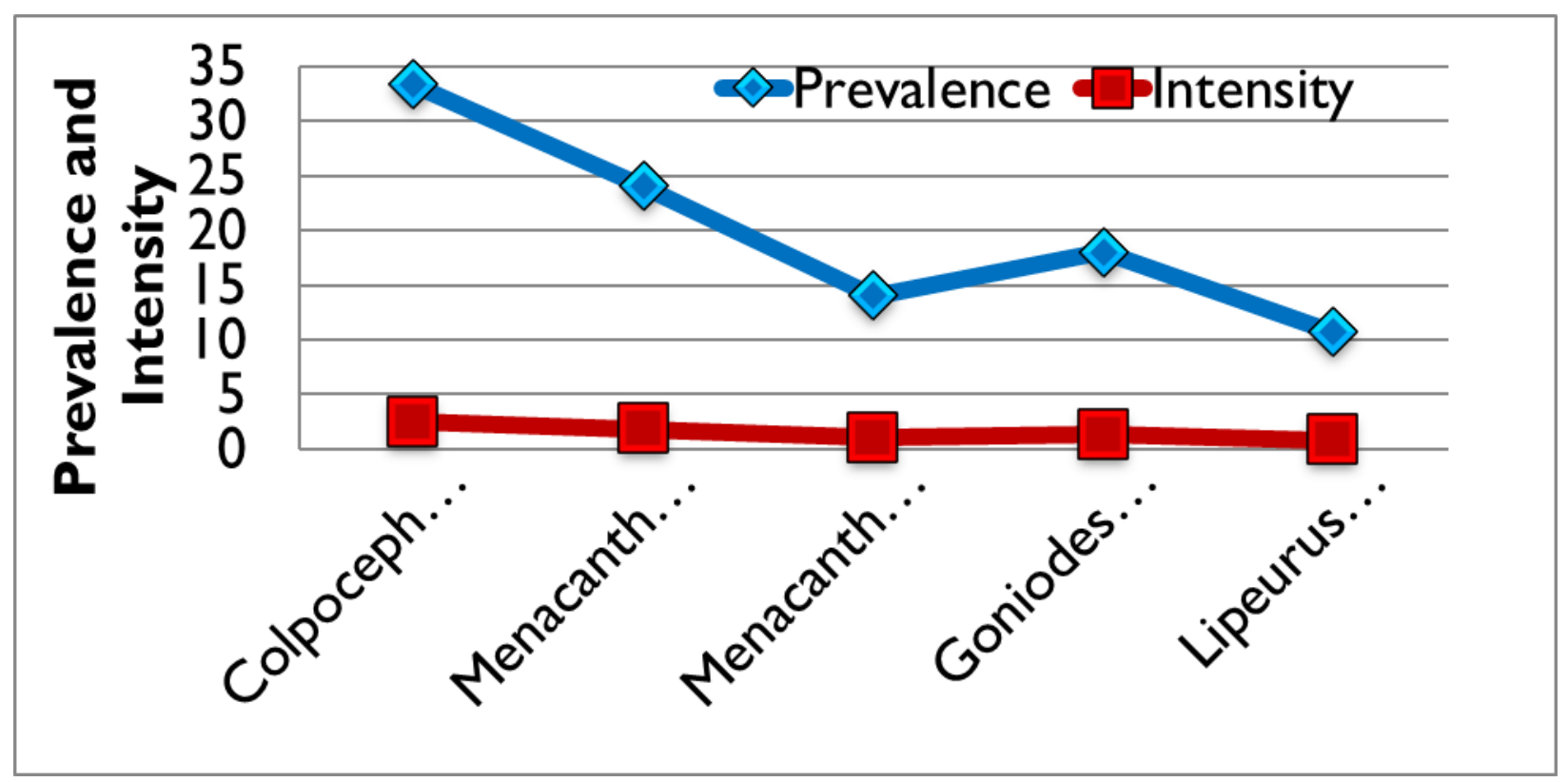

Figure 3. Comparative numbers of chewing lice showing intensity and abundance of lice species on infested host

\section{Conclusion}

The present study is aimed to encounter the chewing lice (Phthiraptera) species of Common pea fowls (Galliformes: Phasianidae), which one economically important bird, and used as (Poultry birds). Poultry birds are important game birds and used as valuable food and used for game. The present study also provides a basic knowledge to identify the chewing lice as ectoparasites of the poultry and awareness to the poultry breeders and hence to improve the production of poultry. The research work on chewing lice parasites of Common pea fowls found in Hyderabad, Sindh, Pakistan concludes that the fowls harbor various species of chewing lice parasites on them. These chewing lice species were identified as Colpocephalum tausi (Nitzsch, 1818), Menacanthus stramineus (Nitzsh, 1818), Menacanthus pallidulus (Neumann, 1912), Goniodes dissimilis Denny, 1842 and Lipeurus tropicalis, Peters, 1931.

Authors' contributions

Conceived and designed the experiments: NA Birmani, Performed the experiments: F Shaikh \& S Naz, Analyzed the data: S Naz, Contributed materials/ analysis/ tools: $\mathrm{S} \mathrm{Naz}$
\& NA Birmani, Wrote the paper: F Shaikh \& S Naz.

\section{Acknowledgement}

This research work is extremely reinforced and sponsored by under research development project: 20/4514/NRPU/R and D/HEC/14/454.

\section{References}

1. Ansari MAR (1956). Studies on Phthirapteran parasites (Mallophaga) infesting birds in the Punjab. Indian $J$ Entomol 17(3): 394-400.

2. Salim AA (1927). The Moghal emperors of India as naturalists and sportsman (Part III). J Bombay Nat Hist Soc 32(2): 264273.

3. Grimmett $\mathrm{R}$, Inskipp $\mathrm{C}$, \& Inskipp $\mathrm{T}$ (2012). Birds of India: Pakistan, Nepal, Bangladesh, Bhutan, Sri Lanka and the Maldives, Princeton Field Guides. 13p

4. Petrie M, Halliaday $\mathrm{T}$, \& Sanders C (1991). Peahens prefer peacocks with elaborate trains. Anim Bevav 41(2): 323-331. 
5. Petrie M (1992). Peacock with low mating success is more likely to suffer predation. Anim Behav 44: 585-586.

6. Roberts TJ (1991). The Birds of Pakistan. Vol. I. Non-Passeriformes. Oxford University Press. Karachi. pp. 598.

7. Salim AA (1927). The Moghal emperors of India as naturalists and sportsman (Part III). J Bombay Nat Hist Soc 32 (2): 264273.

8. Price RD, Clayton DH, Hallenthal RA, Johnson KP \& Palma RL (2003). The chewing lice: world checklist and biological overview; Illinois Natural History Surey, Special Publication 24: 1$105+\mathrm{X}$.

9. Ansari MAR (1946). Association between the Mallophaga \& the Hippoboscidae infesting birds. J Bombay Nat Hist Soc 46(3): 509-516.

10. Ansari MAR (1947). Mallophaga (Ischnocera) infesting birds in the Punjab (India). Proc Nat Inst Sci India 13(6): 253-303.

11. Ansari MAR (1955). Studies on the Ischnoceran Mallophaga, infesting birds in Pakistan. Proc Pak Sci Conf Agri Bahawalpur Sec Biol 7: 52-53.

12. Ansari MAR (1959). Studies on Ischnoceran Mallophaga infesting birds in the Punjab. Indian J Entomol 20(2): 77-103.

13. Naz S, Rizvi SA \& Akhtar MA (2011). Records of chewing lice (Phthiraptera) on different birds of Phasianidae (Galliformes) from Sindh Pakistan. Pak J Entomol Karachi 26(2): 153156.

14. Naz S, Rajpar AA \& Chandio AH (2016). New Records of some Phthiraptera (chewing lice) of birds from urban areas of Hyderabad, Sindh, Pakistan. Punjab Uni J Zool 31(2): 193-201.

15. Palma RL (1978). Side-mounting of lice: A detailed description of the Canada balsam technique. NZ Entomol 6(4): 432436.

16. Ash JS (1960). A study of Mallophaga of birds with particular reference to their ecology. Ibis 102: 93-110.

17. Syeed K, Rizvi SA \& Naz S (2005). Seasonal effects on the population of chicken lice (Mallophaga: Insecta). $I J B B$ 2(4): 921-924.

18. Clayton DH, Koop JAH, Harbison CW, Moyer BR \& Bush SE (2010). How birds combat ectoparasites. Open Ornithol J 3: 41-71. 